Article

\title{
A Laboratory Approach on the Hybrid-Enhanced Oil Recovery Techniques with Different Saline Brines in Sandstone Reservoirs
}

\author{
Yisheng $\mathrm{Hu}^{1, *}$, Qiurong Cheng ${ }^{1}$, Jinping Yang ${ }^{2}$, Lifeng Zhang ${ }^{2}$ and Afshin Davarpanah ${ }^{3, *}$ (i) \\ 1 State Key Laboratory of Oil and Gas Reservoir Geology and Exploitation, Southwest Petroleum University, \\ Chengdu 610500, China; Cheng1993.spu@gmail.com \\ 2 Research Institute of Exploration and Development, Xinjiang Oilfield Company, PetroChina, \\ Karamay 834000, China; Jinping.2013yang@yahoo.com (J.Y.); Zhang.14523.li@gmail.com (L.Z.) \\ 3 Department of Mathematics, Aberystwyth University, Aberystwyth SY23 3FL, UK \\ * Correspondence: schuysheng@163.com (Y.H.); afd6@aber.ac.uk (A.D.)
}

Received: 15 July 2020; Accepted: 26 August 2020; Published: 28 August 2020

check for updates

\begin{abstract}
As foams are not thermodynamically stable and might be collapsed, foam stability is defined by interfacial properties and bulk solution. In this paper, we investigated foam injection and different salinity brines such as $\mathrm{NaCl}, \mathrm{CaCl}_{2}, \mathrm{KCl}$, and $\mathrm{MgCl}_{2}$ to measure cumulative oil production. According to the results of this experiment, it is concluded that sequential low-salinity water injections with $\mathrm{KCl}$ and foam flooding have provided the highest cumulative oil production in sandstone reservoirs. This issue is related to high wettability changes that had been caused by the $\mathrm{KCl}$. As $\mathrm{K}^{+}$is a monovalent cation, $\mathrm{KCl}$ has the highest wettability changes compared to other saline brines and formation water at $1000 \mathrm{ppm}$, which is due to the higher wettability changes of potassium $\left(\mathrm{K}^{+}\right)$over other saline ions. The interfacial tension for $\mathrm{KCl}$ at the lowest value is $1000 \mathrm{ppm}$ and, for $\mathrm{MgCl}_{2}$, has the highest value in this concentration. Moreover, the formation brine, regarding its high value of salty components, had provided lower cumulative oil production before and after foam injection as it had mobilized more in the high permeable zones and, therefore, large volumes of oil would be trapped in the small permeable zones. This was caused by the low wettability alteration of the formation brine. Thereby, formation water flowed in large pores and the oil phase remained in small pores and channels. On the other hand, as foams played a significant role in the mobility control and sweep efficiency, at 2 pore volume, foam increased the pressure drop dramatically after brine injection. Consequently, foam injection after $\mathrm{KCl}$ brine injection had the maximum oil recovery factor of $63.14 \%$. $\mathrm{MgCl}_{2}$ and formation brine had $41.21 \%$ and $36.51 \%$ oil recovery factor.
\end{abstract}

Keywords: low-salinity water; foam flooding; wettability change; cumulative oil production; sandstone reservoirs

\section{Introduction}

Low-salinity water (LSW) flooding is considered as one of the efficient enhanced oil recovery (EOR) methods which are under establishment in many research institutes; however, the polymer can help in the improvement of sweep efficiency. LSW was first implemented in the offshore oilfields of Endicott in Alaska to enhance the original oil in place for about 6-12\% [1-6]. After that, it has been administered in Omar Oilfield in Syria to investigate the wettability alteration, which is caused by low-salinity and high-salinity water (HSW) flooding. The results of this experimental field evaluation depicted that LSW flooding has a greater oil recovery factor than HSW flooding. The reason for this issue is the capability of low-salinity brines to provide more wettability changes and subsequently to obtain more oil recovery factor [7-12]. 
Foam application for the oil recovery enhancement was firstly expressed by McPhee et al. (1988) to improve the sweep efficiency of gas drives. Due to the higher interactions between foams and formation, a large percent of foam flooding performances have been carried out in water-wet rocks where no oil existed [13-16]. Some concepts, which should be of importance in foam-flow behavior, are the Marangoni effect, gravity drainage, disjoining pressure, entering and spreading, interfacial tension, diffusion, liquid drainage by gravity, and liquid viscosity [17-21]. The Marangoni effect is considered as the mass transfer of the fluid phase through the interfacial surfaces of two regions which are caused by surface tension. In low concentrations of surfactants, surface tension has been increased, which caused surface contraction instead of low energy maintenance [22-24]. The surface contraction would cause the inducement of the fluid to flow from low tension areas to high tension areas, which would provide resistance versus the liquid film. This phenomenon helps to stabilize the foam and it is also named surface elasticity. As foams are divided within very thin layers, gravity drainage would cause liquid to drain from the liquid layers. Disjoining pressure is contributed to the overlapping of the two surface layers regarding the impacts of the total forces [6,25]. Entering is another issue which is considered as the film ruptures by the oil droplet which should be entered in the interfacial surfaces between water and gas and then the oil is spread through the interface of the solution gas that is called spreading. Both of these issues would be considered as the free energy system to generate the new gas-oil interface (antifoam liquid) and impact the original process of foam generation [26-28]. Interfacial tension is another critical parameter which is considered as the provided energy to generate bubbles and if this energy is low, the bubbles will form easier; however, the lower interfacial tension would not guarantee the foam stability as it needs a specific energy strength to be more stable. Regarding the non-uniform distribution size of the gas bubbles, large bubbles have lower pressure than small bubbles which can cause the chemical differences. Therefore, the gas would diffuse into the liquid phase from smaller to larger bubbles that have caused the coalescence [29-32].

Osei-Bonsu et al. (2015) investigated the considerable influence of different surfactants on foam stability in the presence and absence of three iso-paraffins. They found that surfactants play a significant role in foam stability, especially in the absence of oil phase [33]. Soltanian et al. (2019) proposed a coupling model to consider the geochemical reactions and thermodynamic effect of carbon dioxide-brine during carbon dioxide injection. They concluded that reservoir characteristics such as porosity and permeability have affected carbon dioxide transport and fate. Moreover, the chemical and physical properties of fluvial channels are within the important parameters of the carbon dioxide transport and fate that should be taken into consideration during carbon capture and storage projects [34]. As salty brines transport in porous media, Dashtian et al. (2018) proposed a pore network model to predict the capillary effect, vapor diffusion, and salt transport in the pore scale. They concluded that pore throat connectivity, clustering and drying patterns, and saturation distribution are utterly dependent on the distribution of pore sizes [35].

Nell (2015) proposed that oil presence and rock wettability would play a substantial role in the foam flooding performances. In this, the oil became more destabilized when it came into contact with a foaming agent. He concluded that one of the efficient ways to overcome this instability is to alter the reservoir rock wettability [36]. This can be performed by hybrid-enhanced oil recovery techniques, which have contained sequential chemical flooding and low-water salinity. Hosseinzade Khanamiri et al. (2016) proposed a hybrid-enhanced oil recovery technique that included a surfactant and LSW injection in sandstone reservoirs. This method could provide a noticeable wettability alteration and the utilization of HSW has had the lowest wettability changes [37]. Dang et al. (2020) proposed mechanistic-hybrid chemical-enhanced oil recovery techniques that were combined with LSW flooding to consider a multilayer artificial network as an artificially intelligent method to investigate the efficiency of geochemistry properties. They considered different chemical agents such as surfactant, polymer and water salinities and their profound impact on the alteration of relative permeability changes. They concluded that surfactant and low-salinity water injectivity would be an optimum hybrid-enhanced oil recovery method [38]. 
Bakhshian et al. (2020) investigated the combined effects of pore geometry and wettability alteration for the displacement of two-phase fluid by the utilization of the lattice Boltzmann model at different contact angles. According to their results, complex interactions of pore morphology and wettability would be a significant controlling parameter for the displacement efficiency, both in heterogeneous and homogenous porous media [39]. Feng et al. (2020) considered that the non-confinement influence contained a shift critical temperature and curvature dependent effect on nanopores. They found that the non-confinement effect on the nanometer pore sizes (it would be more sensitive especially with a decrease in pore sizes) had reduced the surface tension [40].

As sandstones have negative surface charges, they tend to adsorb monovalent cations instead of divalent cations. Therefore, as $\mathrm{K}^{+}$is a monovalent cation, $\mathrm{KCl}$ has the highest wettability changes compared to other saline brines [41]. After that, $\mathrm{Na}^{+}$(monovalent cation), $\mathrm{Ca}^{2+}$ and $\mathrm{Mg}^{2+}$ (divalent cations) were selected as preferable low-saline brines for flooding performances. This issue can be illustrated by reactivity series. Thereby, $\mathrm{K}^{+}$is intended more easily with clay surfaces than other cations. Awolayo et al. (2018) and Jackson et al. (2016) proposed a review study on the interactions between rock, oil and brines and how various brine contents and ionic strengths can improve sweep efficiency in sandstone and carbonate reservoirs [41,42].

We aimed to investigate hybrid chemical-enhanced oil recovery techniques (especially foam flooding) with the utilization of different water salinities that contained $\mathrm{NaCl}, \mathrm{CaCl}, \mathrm{KCl}$, and $\mathrm{MgCl}_{2}$ to measure cumulative oil production, interfacial tension, pressure drop, and select the optimum-enhanced oil recovery methods in sandstone reservoirs.

\section{Materials and Methods}

\subsection{Materials}

The selected core samples were extracted from Pazanan oil field in the southwest of Iran with $4.1 \mathrm{~cm}$ of outer diameter and $8.24 \mathrm{~cm}$ length. The porosity of the core samples is about $18.5 \%$ and the average permeability to formation brine is $90 \mathrm{mD}$. The dynamic viscosity of crude oil is measured in two different temperatures of $25^{\circ} \mathrm{C}$ and $85{ }^{\circ} \mathrm{C}$. It is $3.594 \mathrm{mPa}$-s and $1.652 \mathrm{mPa}$-s, respectively. Crude oil density is $0.765 \mathrm{~g} / \mathrm{cm}^{3}$. Carbon dioxide was used as an immiscible gas with a purity of $99.9 \%$. Four types of brine were used with a different concentration in this study. $\mathrm{KCl}$ and $\mathrm{MgCl}_{2}, \mathrm{CaCl}_{2}$, and $\mathrm{NaCl}$ are considered as low-salinity brine and formation brine is considered as high salinity. Brine properties for each type are expressed in Table 1.

Table 1. Brine properties for each type.

\begin{tabular}{cccccc}
\hline Brine Type & TDS (mg/L) & $\mathbf{p H}\left(25^{\circ} \mathbf{C}\right)$ & $\mathrm{pH}\left(\mathbf{8 5}{ }^{\circ} \mathbf{C}\right)$ & $\begin{array}{c}\text { Density } \\
\left(25^{\circ} \mathbf{C}\right) \mathbf{g} / \mathbf{c m}^{\mathbf{3}}\end{array}$ & $\begin{array}{c}\text { Density } \\
\left(85^{\circ} \mathbf{C}\right) \mathbf{g} / \mathbf{c m}^{3}\end{array}$ \\
\hline $\mathrm{KCl}$ & $1000-6000$ & $6.6-6.9$ & $6.5-6.8$ & $1-1.0045$ & $0.985-0.99$ \\
\hline $\mathrm{MgCl}_{2}$ & $1000-6000$ & $6.8-7.1$ & $6.65-7$ & $0.95-1$ & $0.98-0.985$ \\
\hline $\mathrm{CaCl}_{2}$ & $1000-6000$ & $6.7-7.1$ & $6.5-7$ & $1.0002-1.003$ & $0.98-0.985$ \\
\hline $\mathrm{NaCl}$ & $1000-6000$ & $6.21-6.68$ & $6.12-6.53$ & $1-1.0025$ & $0.975-0.98$ \\
\hline Formation Brine & 120,000 & 7.2 & 7.05 & 1.025 & 0.98 \\
\hline
\end{tabular}

The foaming agent contains sodium alpha-olefin sulfate with active matter of $38 \%$ and different shear rates, e.g., 5 to $500 \mathrm{~s}^{-1}$. Moreover, the average apparent viscosity is about $345 \mathrm{mPa}$-s.

\subsection{Methods}

In this paper, we focused on the measurement of oil recovery factor from a sandstone reservoir and compared different brine salinities with chemical flooding methods. 


\subsubsection{Wettability Measurement}

By using the contact angle method, rock wettability was obtained in different brine salinities to choose an optimum brine salinity that can alter the rock wettability and provide higher recovery factors. To do this, core slices with the thickness of 3-5 $\mathrm{mm}$ were cut, and they were cleaned by toluene. Then they were dried out for one day in temperature of $105^{\circ} \mathrm{C}$. Finally, the core slices were saturated in temperature of $80^{\circ} \mathrm{C}$ for three days. The wettability was measured in different brine salinities in the presence of oil. As sandstone reservoirs have mainly consisted of quartz, petroleum industries have preferred to use the contact angle method as it is a direct method and considered as an economic method.

\subsubsection{Interfacial Tension and Foam Stability Measurement}

Then, we measured interfacial tension and foam stability to select the foam that is more stable in the presence of oil and can reduce the interfacial tension accordingly to enhance the oil recovery factor. Finally, core flooding experiments were performed to compare different scenarios and check their efficiency on the recovery factor. To measure interfacial tension, we used a spinning drop technique and to measure the foam stability we set aside performances of two different temperatures of $25^{\circ} \mathrm{C}$ and $65^{\circ} \mathrm{C}$ to be observed in the laboratory condition. More details of these two tests are explained in Davarpanah (2018) paper [6].

\subsubsection{Core Flooding Procedure}

The components of the core flooding apparatus are shown in Figure 1. The following procedures were performed sequentially:

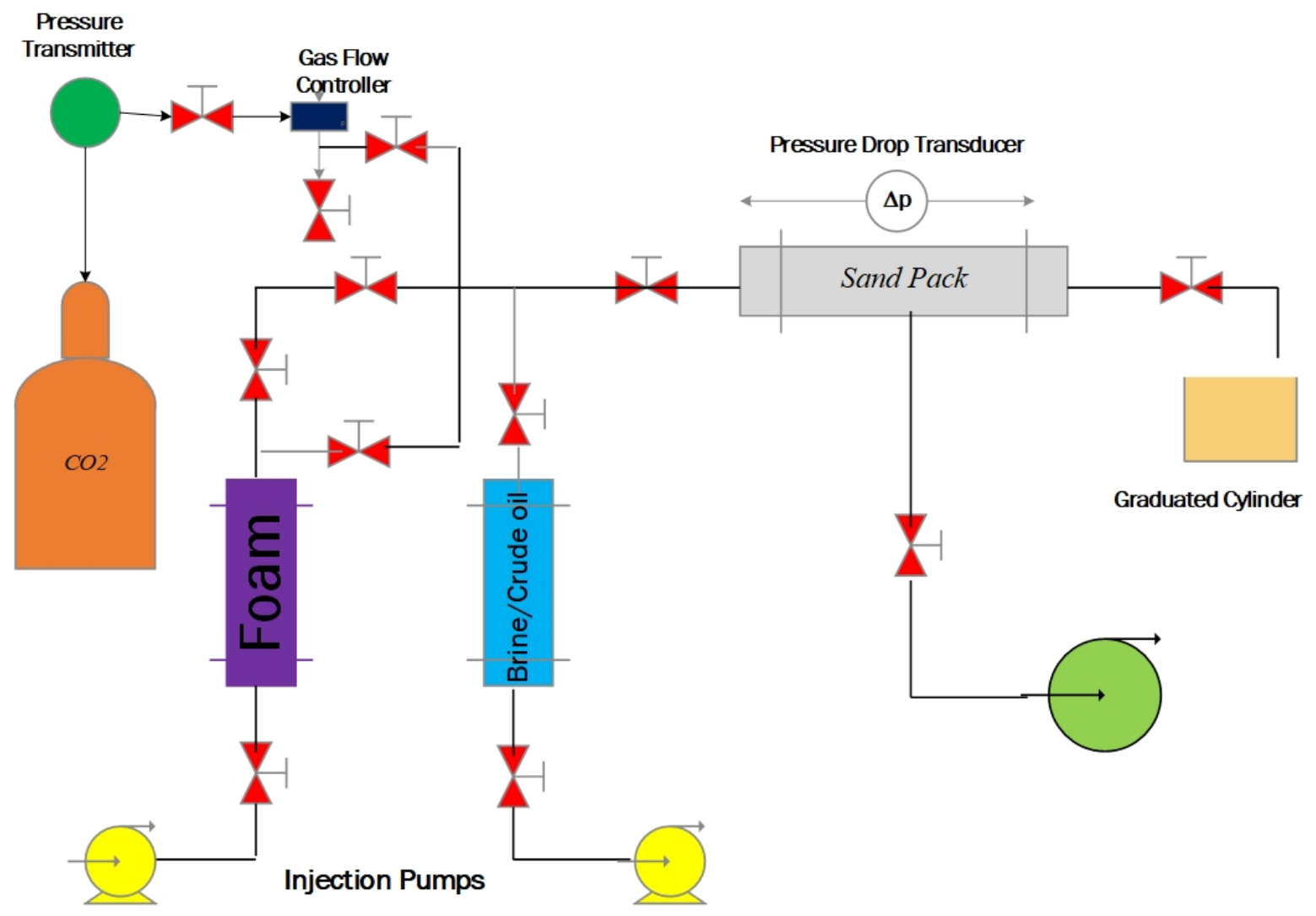

Figure 1. Core flooding apparatus.

(1) Core plug is used to provide the fluid flow through the core at a defined operational temperature of $60^{\circ} \mathrm{C}$ and pressure (confining pressure is about $2600 \mathrm{Psi}$ ). 
(2) $0.2 \mathrm{~cm}^{3} / \mathrm{min}$ of formation brine was injected into the system and it was continued until the pressure drop was stabilized to obtain initial water saturation.

(3) The injection was stopped, and absolute permeability was measured accordingly.

(4) The water flooding procedure was performed with different salinities and formation brine at $0.3 \mathrm{~cm}^{3} / \mathrm{min}$ flow rate.

(5) Chemical agents and carbon dioxide (with a working pressure of 1720 Psi) at $0.5 \mathrm{~cm}^{3} / \mathrm{min}$ is injected into the core samples in the miscible condition. Water cut reached 99\% [43].

\section{Results and Discussion}

\subsection{Interfacial Tension}

As sandstones have negative surface charges, they tend to adsorb monovalent cations instead of divalent cations. Therefore, as $\mathrm{K}^{+}$is a monovalent cation, $\mathrm{KCl}$ has the highest wettability changes compared to other saline brines and formation water at $1000 \mathrm{ppm}$; this is due to the higher wettability changes of potassium $\left(\mathrm{K}^{+}\right)$over other saline ions. After that, $\mathrm{Na}^{+}$(monovalent cation), $\mathrm{Ca}^{2+}$ and $\mathrm{Mg}^{2+}$ (divalent cations) were selected as preferable low-saline brines for flooding performances. This issue can be illustrated by reactivity series. Thereby, $\mathrm{K}^{+}$is intended more easily with clay surfaces than other cations. This issue was discussed by Shabib-Asl et al. (2015) [44]. Interfacial tension measurements for different saline brines and formation brine are plotted in Figure 2. The interfacial brines are measured for all the brines in $1000 \mathrm{ppm}$, and the formation brine concentration is 12,000 ppm. According to Figure 2, the interfacial tension for $\mathrm{KCl}$ at the lowest value is $1000 \mathrm{ppm}$ and, for $\mathrm{MgCl}_{2}$, has the highest value in this concentration.

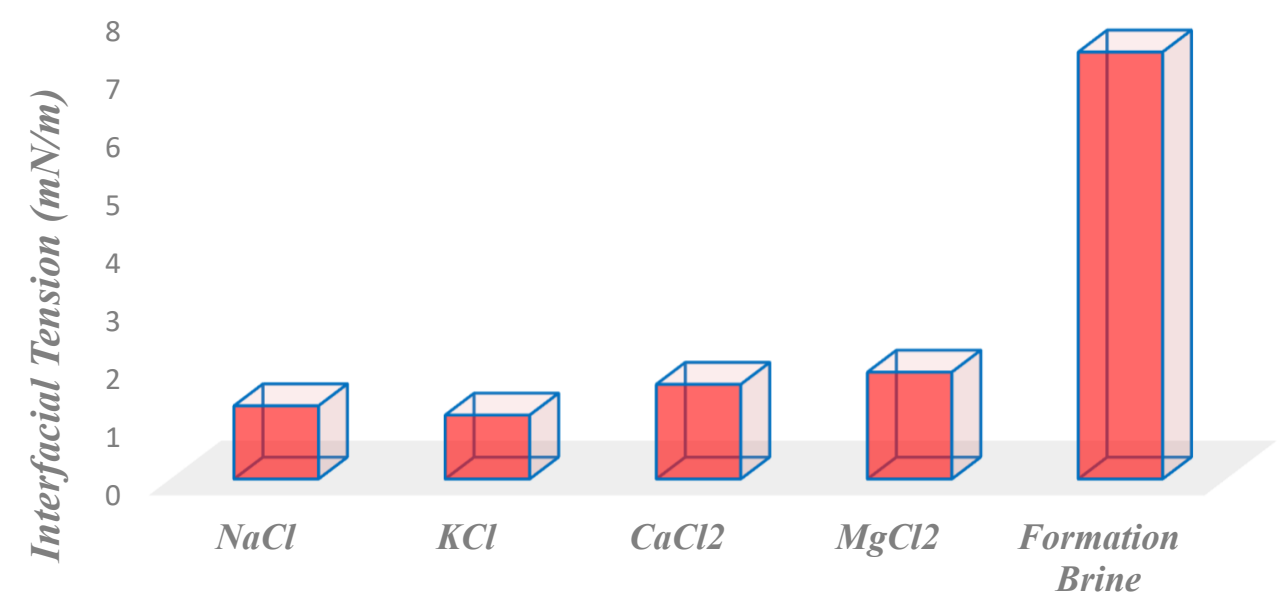

Brines Component

Figure 2. Interfacial tension measurement for different brine components.

\subsection{Cumulative Oil and Water Production}

Water production during each scenario is plotted in Figure 3. In the first period of injection, water production has increased dramatically and then it has been stabilized. Formation brine has provided more volumes of water production over other saline brines. Cumulative oil production is plotted in Figure 3 to compare the effect of each brine type with foam injectivity. Due to the higher wettability alteration of KCL, cumulative oil production has the maximum value and formation water has the lowest oil production. This is caused by the low wettability alteration of formation brine. Thereby, formation water flowed in large pores and the oil phase has remained in small pores and channels.

Foams have played an important role in enhancing the oil recovery factor due to their efficiency in the mobility control. As can be seen in Figure 4, after two pore volumes, the foam was injected into 
the core samples. $\mathrm{KCl}$, as an LSW injection, had provided the highest oil production rather than other scenarios regarding the highest wettability change of $\mathrm{KCl}$. Furthermore, as the salty components are high in the formation water, the oil production is lower than other LSW scenarios.

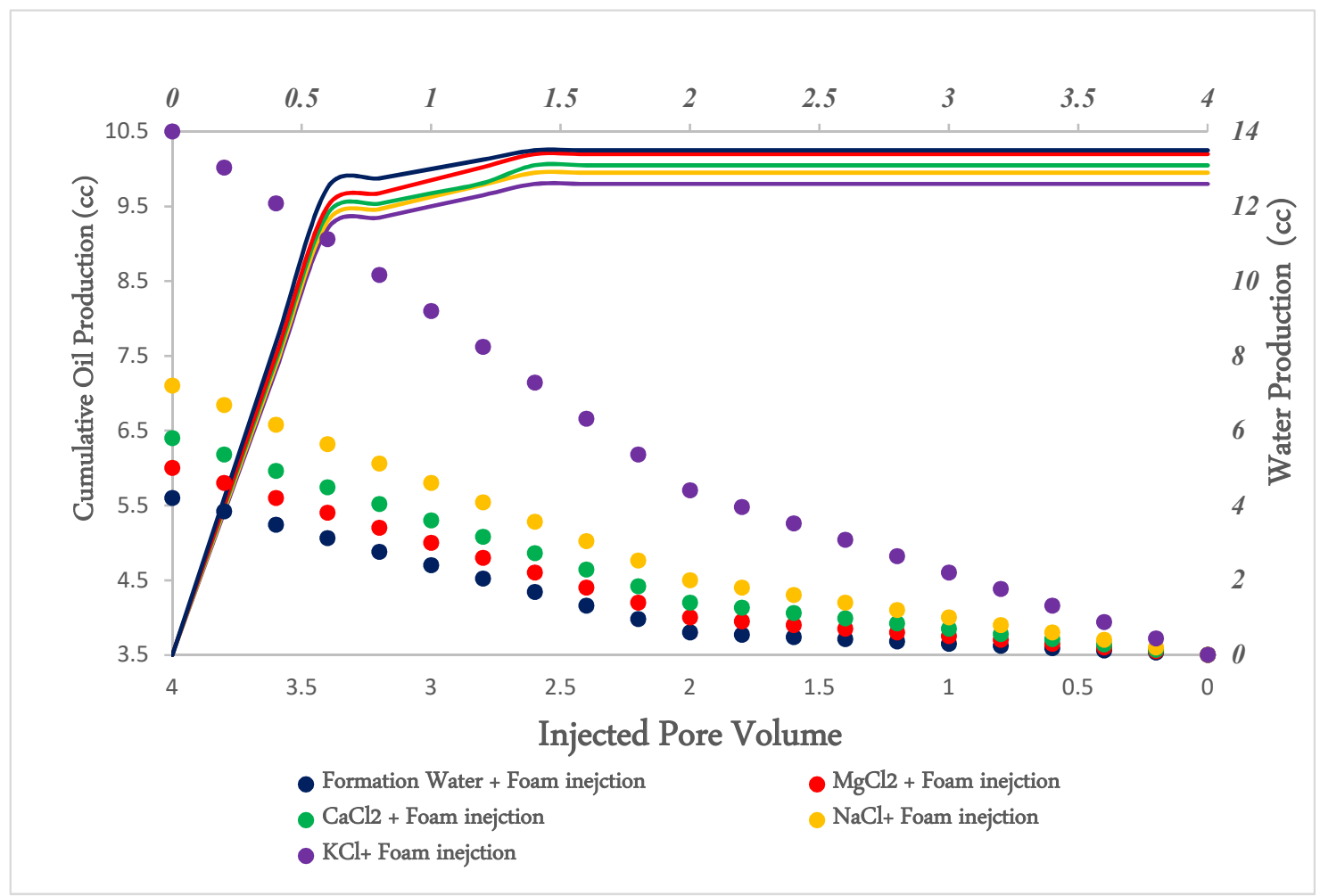

Figure 3. Cumulative oil and water production for different brine components.

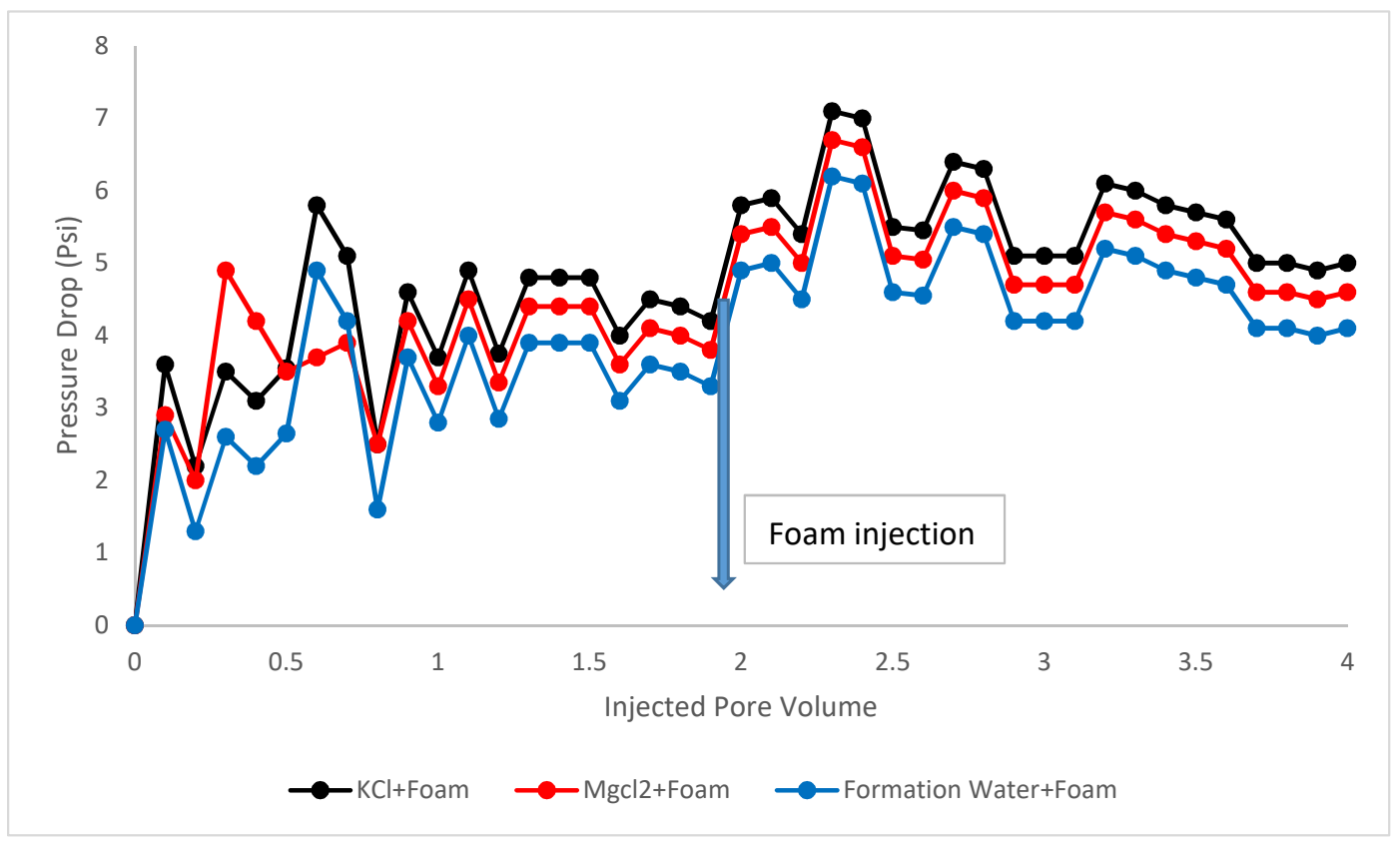

Figure 4. Pressure drop for different scenarios. 


\subsection{Pressure Drop}

In this part of the study, we focused on the pressure drop measurement for different injectivity scenarios. KCL (monovalent cation), $\mathrm{MgCl}_{2}$ (divalent cation), and formation brine were injected and at 2 pore volume (PV), foam injection started. As is evident in Figure 4, foams have played a significant role in the pressure drop increase from $2 \mathrm{PV}$ to $4 \mathrm{PV}$. The reason for this increase was related to the higher wettability changes and the foam column being more stable, which caused an increase in pressure drop at $2 \mathrm{PV}$. This caused more mobility control and sweep efficiency. It was about 6 Psi, 5.4 Psi, and 3 Psi for the foam flooding injection after $\mathrm{KCL}, \mathrm{MgCl}_{2}$, and formation brine injection. $\mathrm{KCl}$ provided more pressure drop when foams had been injected at $2 \mathrm{PV}$ as it is a monovalent cation and, hence, it provided more wettability changes in sandstone reservoirs. After that, $\mathrm{MgCl}_{2}$ and formation water entered the second and third stage of the pressure drop before foam injectivity.

Table 2 illustrates the summary of the results for foam injection after KCL (monovalent cation), $\mathrm{MgCl}_{2}$ (divalent cation), and formation brine. As is evident, foam injection after $\mathrm{KCl}$ brine injection has the maximum oil recovery factor of $63.14 \% . \mathrm{MgCl}_{2}$ and formation brine has a $41.21 \%$ and $36.51 \%$ oil recovery factor.

Table 2. Summary of results.

\begin{tabular}{cccc}
\hline Parameter & KCL + Foam & $\mathbf{M g C l}_{\mathbf{2}}+$ Foam & Formation brine + Foam \\
\hline Initial oil saturation & 0.840 & 0.841 & 0.832 \\
\hline Initial water saturation & 0.160 & 0.158 & 0.161 \\
\hline Residual oil saturation & 0.58 & 0.58 & 0.58 \\
\hline Oil recovery (\%) & 63.14 & 41.21 & 36.51 \\
\hline Original oil in place (\%) & 77.5 & 50.34 & 42.7 \\
\hline
\end{tabular}

\section{Conclusions}

Chemical flooding has always been considered as one of the efficient techniques in sandstone reservoirs because of its increased compatibility with reservoir characteristics. In this paper, we tried to provide a set of LSW injections with different saline brines and foam flooding to measure cumulative oil production. According to the results of this experiment, it is concluded that sequential LSW injection with $\mathrm{KCl}$ and foam flooding has provided the highest cumulative oil production in sandstone reservoirs. This issue is related to the high wettability changes that were caused by the $\mathrm{KCl}$. Moreover, formation brine, regarding its high value of salty components, had provided lower cumulative oil production before and after foam injection as it had mobilized more in the high permeable zones and, therefore, large volumes of oil would be trapped in the small permeable zones.

Author Contributions: Conceptualization, Y.H. and Q.C.; methodology, J.Y.; software, L.Z.; validation, Y.H., A.D. and L.Z.; formal analysis, A.D.; investigation, Z.C.; resources, A.D.; data curation, A.D.; writing-original draft preparation, Y.H.; writing-review and editing, A.D.; visualization, A.D.; supervision, A.D.; project administration, A.D.; funding acquisition, Y.H. All authors have read and agreed to the published version of the manuscript.

Funding: This research received no external funding.

Acknowledgments: Supported by the National Natural Science Foundation of China (No. 41702286); supported by Innovation Fund of China National Petroleum Corporation (2018D-5007-0209); supported by Sichuan Science and Technology Program (18GJHZ0206, No. 20QYCX0030).

Conflicts of Interest: The authors declare no conflict of interest.

\section{References}

1. Lager, A.; Webb, K.J.; Black, C.J.J.; Singleton, M.; Sorbie, K.S. Low salinity oil recovery-an experimental investigation. Petrophysics 2008, 49, 28-35. 
2. Gao, Y.; Zhao, M.; Wang, J.; Zong, C. Performance and gas breakthrough during $\mathrm{CO}_{2}$ immiscible flooding in ultra-low permeability reservoirs. Pet. Explor. Dev. 2014, 41, 88-95. [CrossRef]

3. Bartels, W.-B.; Mahani, H.; Berg, S.; Hassanizadeh, S. Literature review of low salinity waterflooding from a length and time scale perspective. Fuel 2019, 236, 338-353. [CrossRef]

4. Takeya, M.; Shimokawara, M.; Elakneswaran, Y.; Nawa, T.; Takahashi, S. Predicting the electrokinetic properties of the crude oil/brine interface for enhanced oil recovery in low salinity water flooding. Fuel 2019, 235, 822-831. [CrossRef]

5. Pan, F.; Zhang, Z.; Zhang, X.; Davarpanah, A. Impact of anionic and cationic surfactants interfacial tension on the oil recovery enhancement. Powder Technol. 2020, 373, 93-98. [CrossRef]

6. Davarpanah, A. A feasible visual investigation for associative foam $>\backslash$ polymer injectivity performances in the oil recovery enhancement. Eur. Polym. J. 2018, 105, 405-411. [CrossRef]

7. Mahani, H.; Sorop, T.; Ligthelm, D.J.; Brooks, D.; Vledder, P.; Mozahem, F.; Ali, Y. Analysis of field responses to low-salinity waterflooding in secondary and tertiary mode in Syria. In Proceedings of the SPE Europec/EAGE Annual Conference and Exhibition, Vienna, Austria, 23-26 May 2011.

8. Nasralla, R.A.; Alotaibi, M.B.; Nasr-El-Din, H.A. Efficiency of Oil Recovery by Low Salinity Water Flooding in Sandstone Reservoirs. In Proceedings of the SPE Western North American Region Meeting, Anchorage, AK, USA, 7-11 May 2011.

9. Akai, T.; Blunt, M.J.; Bijeljic, B. Pore-scale numerical simulation of low salinity water flooding using the lattice Boltzmann method. J. Colloid Interface Sci. 2020, 566, 444-453. [CrossRef]

10. Takeya, M.; Shimokawara, M.; Elakneswaran, Y.; Okano, H.; Nawa, T. Effect of Acid Number on the Electrokinetic Properties of Crude Oil during Low-Salinity Waterflooding. Energy Fuels 2019, 33, 4211-4218. [CrossRef]

11. Haiyan, Z.; Davarpanah, A. Hybrid Chemical Enhanced Oil Recovery Techniques: A Simulation Study. Symmetry 2020, 12, 1086.

12. Esfandyari, H.; Shadizadeh, S.R.; Esmaeilzadeh, F.; Davarpanah, A. Implications of anionic and natural surfactants to measure wettability alteration in EOR processes. Fuel 2020, 278, 118392. [CrossRef]

13. McPhee, C.A.; Tehrani, A.D.H.; Jolly, R.P.S. Foam flooding of cores under North Sea reservoir conditions. In Proceedings of the SPE Enhanced Oil Recovery Symposium, Tulsa, OK, USA, 16-21 April 1988.

14. Davarpanah, A.; Mirshekari, B. A mathematical model to evaluate the polymer flooding performances. Energy Rep. 2019, 5, 1651-1657. [CrossRef]

15. Davarpanah, A.; Mirshekari, B. Mathematical modeling of injectivity damage with oil droplets in the waste produced water re-injection of the linear flow. Eur. Phys. J. Plus 2019, 134, 180. [CrossRef]

16. Hu, X.; Xie, J.; Cai, W.; Wang, R.; Davarpanah, A. Thermodynamic effects of cycling carbon dioxide injectivity in shale reservoirs. J. Pet. Sci. Eng. 2020. [CrossRef]

17. Schramm, L.L.; Wassmuth, F. Foams: Basic Principles; American Chemical Society: Washington, DC, USA, 1994; pp. 3-45.

18. Wang, J.; Nguyen, N.-T.; Farrokhpay, S. A critical review of the growth, drainage and collapse of foams. Adv. Colloid Interface Sci. 2016, 228, 55-70. [CrossRef]

19. Stevenson, P. Foam Engineering: Fundamentals and Applications; John Wiley \& Sons: Hoboken, NJ, USA, 2012.

20. Yu, X.; Jiang, N.; Miao, X.; Li, F.; Wang, J.; Zong, R.; Lu, S. Comparative studies on foam stability, oil-film interaction and fire extinguishing performance for fluorine-free and fluorinated foams. Process Saf. Environ. Prot. 2020, 133, 201-215. [CrossRef]

21. Lu, W.; Davarpanah, A. An experimental investigation to consider thermal methods efficiency on oil recovery enhancement. Heat Transf. 2020, 49, 3066-3074. [CrossRef]

22. Hu, Y.; Wang, H.; Song, M.; Huang, J. Marangoni effect on microbubbles emission boiling generation during pool boiling of self-rewetting fluid. Int. J. Heat Mass Transf. 2019, 134, 10-16. [CrossRef]

23. Ezquerro, J.; Sánchez, P.S.; Bello, A.; Rodríguez, J.; Lapuerta, V.; Laveron-Simavilla, A. Experimental evidence of thermocapillarity in phase change materials in microgravity: Measuring the effect of Marangoni convection in solid/liquid phase transitions. Int. Commun. Heat Mass Transf. 2020, 113, 104529. [CrossRef]

24. Abir, F.M.; Barua, S.; Barua, S.; Saha, S. Numerical analysis of Marangoni effect on natural convection in two-layer fluid structure inside a two-dimensional rectangular cavity. In Proceedings of the 8th BSME International Conference on Thermal Engineering, Dhaka, Bangladesh, 19-21 December 2018. 
25. Davarpanah, A.; Mirshekari, B. Numerical simulation and laboratory evaluation of alkali-surfactant-polymer and foam flooding. Int. J. Environ. Sci. Technol. 2019, 17, 1123-1136. [CrossRef]

26. Boinovich, L.B. Boundary layers and surface forces in pure non-aqueous liquids. Curr. Opin. Colloid Interface Sci. 2019, 44, 85-93. [CrossRef]

27. Ma, T.; Zhou, L.; Du, X.; Yang, Y. Simultaneous measurements of thin film thickness using total internal reflection fluorescence microscopy and disjoining pressure using Scheludko cell. Rev. Sci. Instrum. 2019, 90, 045118. [CrossRef] [PubMed]

28. Zeng, L.; Chen, Y.; Lu, Y.; Lau, H.C.; Hossain, M.; Saeedi, A.; Xie, Q. Interpreting Water Uptake by Shale with Ion Exchange, Surface Complexation, and Disjoining Pressure. Energy Fuels 2019, 33, 8250-8258. [CrossRef]

29. Skauge, A.; Solbakken, J.; Ormehaug, P.A.; Aarra, M.G. Foam Generation, Propagation and Stability in Porous Medium. Transp. Porous Media 2019, 131, 5-21. [CrossRef]

30. Li, Q.; Prigiobbe, V. Studying the generation of foam in the presence of nanoparticles using a microfluidic system. Chem. Eng. Sci. 2020, 215, 115427. [CrossRef]

31. Asiaei, S.; Zadehkafi, A.; Siavashi, M. Multi-layered Porous Foam Effects on Heat Transfer and Entropy Generation of Nanofluid Mixed Convection Inside a Two-Sided Lid-Driven Enclosure with Internal Heating. Transp. Porous Media 2018, 126, 223-247. [CrossRef]

32. Sheng, J.J. Enhanced Oil Recovery Field Case Studies; Gulf Professional Publishing: Houston, TX, USA, 2013.

33. Osei-Bonsu, K.; Shokri, N.; Grassia, P. Foam stability in the presence and absence of hydrocarbons: From bubble- to bulk-scale. Colloids Surf. Physicochem. Eng. Asp. 2015, 481, 514-526. [CrossRef]

34. Soltanian, M.R.; Hajirezaie, S.; Hosseini, S.A.; Dashtian, H.; Amooie, M.A.; Meyal, A.; Ershadnia, R.; Ampomah, W.; Islam, A.; Zhang, X. Multicomponent reactive transport of carbon dioxide in fluvial heterogeneous aquifers. J. Nat. Gas Sci. Eng. 2019, 65, 212-223. [CrossRef]

35. Dashtian, H.; Shokri, N.; Sahimi, M. Pore-network model of evaporation-induced salt precipitation in porous media: The effect of correlations and heterogeneity. Adv. Water Resour. 2018, 112, 59-71. [CrossRef]

36. Nell, M. Oil Foam Interaction: Simulation of Foam Displacement with Oil. Master's Thesis, Delft University of Technology, Delft, The Netherlands, 2015.

37. Khanamiri, H.H.; Enge, I.B.; Nourani, M.; Stensen, J.Å.; Torsæter, O.; Hadia, N. EOR by Low Salinity Water and Surfactant at Low Concentration: Impact of Injection and in Situ Brine Composition. Energy Fuels 2016, 30, 2705-2713. [CrossRef]

38. Dang, C.; Nghiem, L.; Fedutenko, E.; Gorucu, S.E.; Yang, C.; Mirzabozorg, A.; Nguyen, N.; Chen, Z.; Gorocu, S.E. AI based mechanistic modeling and probabilistic forecasting of hybrid low salinity chemical flooding. Fuel 2020, 261, 116445. [CrossRef]

39. Bakhshian, S.; Rabbani, H.S.; Hosseini, S.A.; Shokri, N. New Insights into Complex Interactions Between Heterogeneity and Wettability Influencing Two-Phase Flow in Porous Media. Geophys. Res. Lett. 2020, 47, e2020GL088187. [CrossRef]

40. Feng, D.; Wu, K.; Bakhshian, S.; Hosseini, S.A.; Li, J.; Li, X. Nanoconfinement Effect on Surface Tension: Perspectives from Molecular Potential Theory. Langmuir 2020. [CrossRef] [PubMed]

41. Awolayo, A.N.; Sarma, H.; Nghiem, L.X. Brine-Dependent Recovery Processes in Carbonate and Sandstone Petroleum Reservoirs: Review of Laboratory-Field Studies, Interfacial Mechanisms and Modeling Attempts. Energies 2018, 11, 3020. [CrossRef]

42. Jackson, M.; Vinogradov, J.; Hamon, G.; Chamerois, M. Evidence, mechanisms and improved understanding of controlled salinity waterflooding part 1: Sandstones. Fuel 2016, 185, 772-793. [CrossRef]

43. Hu, X.; Li, M.; Peng, C.; Davarpanah, A. Hybrid Thermal-Chemical Enhanced Oil Recovery Methods; An Experimental Study for Tight Reservoirs. Symmetry 2020, 12, 947. [CrossRef]

44. Shabib-Asl, A.; Ayoub, M.; Elraies, K.A. Laboratory Investigation into Wettability Alteration by different Low Salinity Water Compositions in Sandstone Rock. In Proceedings of the SPE/IATMI Asia Pacific Oil \& Gas Conference and Exhibition, Nusa Dua, Indonesia, 20-22 October 2015.

(C) 2020 by the authors. Licensee MDPI, Basel, Switzerland. This article is an open access article distributed under the terms and conditions of the Creative Commons Attribution (CC BY) license (http://creativecommons.org/licenses/by/4.0/). 